\title{
Ajatuksia ekoindividuaation kasvatusfilosofiasta
}

Jani Pulkki

\section{TIIVISTELMÄ}

- Tässä artikkelissa muotoilen ekoindividuaation ajatusta. Sosialisaation tavoin individuaatio, eli ihmisen ainutlaatuiseksi yksilöksi ja persoonaksi kehittyminen, kuuluu kasvatuksen perustehtäviin. Individuaation ongelmana on individualistinen, kilpailuun, omistamiseen ja hallintaan suuntautunut välineellinen orientaatio. Ihminen ymmärretään ihmiskeskeisesti sekä ihmisen ja luonnon irrallisuuden oletuksen valossa. Muusta luonnosta erillinen ja sen yläpuolella oleva ihminen on ottanut oikeudekseen luonnon pidäkkeettömän käytön ilman velvoituksen tunteita muita eliöitä kohtaan. Yksilöksi kehittyminen, individuaatio, tapahtuu ekologisesti ongelmallisissa puitteissa ja ongelmallisten subjektikäsitysten kehyksessä. Jotta ekokriiseihin voidaan löytää ratkaisuja, onkin kasvatusta ajateltava ekoindividuaatioprosessina, jonka kautta ihminen nivoutuu yksilöllisenä oliona ekosysteemien toiminnalliseksi ja elämää ylläpitäväksi osaksi. Tarkastelen ekoindividuaatiota monilajisissa yhteyksissä systeemisen psykologian, ekopsykologian, ekofenomenologian ja syväekologian valossa. Kahden erillisen eliön ja ympäristön oletuksen sijaan ekoindividuaatio lähtee yhden eliö-ympäristö-systeemin lähtökohdasta. Käsitys oikeudesta kaikkiin luonnon resursseihin (oikeutuksentunto) voi laantua, kun näemme ihmisyksilön olevan lähtökohtaisesti osa ympäristöjä ja keskinäisriippuvaisessa suhteessa näihin. Ekologisen minuuden ajatuksen ja asubjektiivisen kokemuksen avulla tarkastelen sitä, miten ihmisestä voisi kehittyä maapallon elonyhteisön yhteistyökykyinen jäsen eikä tätä vastaan taisteleva individualistinen yksilö.

Avainsanat: Individuaatio, ekoindividuaatio, ympäristökasvatus, kasvatusfilosofia, ekososiaalinen kasvatusfilosofia 


\section{ABSTRACT \\ SOME THOUGHTS ON THE EDUCATIONAL PHILOSOPHY OF ECO-INDIVIDUATION}

- This article formulates an idea of eco-individuation. Both socialization and individuation, the process of developing unique selfhood, are the essential functions of education. The problem with individuation is an individualistic, competitive, possessive, and control-oriented way of thinking. A human being is understood in a human-centered manner assuming human beings are separate from nature. A human being, disengaged from nature also assuming superiority in relation to nature, has considered the unhindered use of nature their inviolable human right without a sense of responsibility towards other living creatures. The development of individuality, individuation takes place in ecologically problematic settings and within problematic ideas of the human subject. Finding solutions to current and ongoing eco-crisis requires rethinking education as a process of eco-individuation, by which human being is intertwined with the ecosystem becoming its constructive member. I examine eco-individuation in multispecies context from the perspectives of systemic psychology, eco-psychology, eco-phenomenology, and deep ecology. Instead of presuming two distinct organism and environment, eco-individuation starts from the standpoint of one organism-environment-system. The human sense of entitlement can subside when seen in fundamental interrelation with other living beings and ecosystems. The ideas of ecological self and asubjective experience are considered for seeing how a human being can grow to be a collaborative member of the Earth's living community and not an individualist person fighting against it.

Keywords: Individuation, eco-individuation, environmental education, educational philosophy, ecosocial philosophy of education

\section{Johdanto}

E lämme ekokriisien aikakautta, joka pakottaa ajattelemaan uudelleen —ähes kaikkia elämäntapamme ulottuvuuksia (Värri 2018). Ilmastonmuutos, kuudes sukupuuttoaalto, mikromuovit ja kemikaalit vesistöissä, pienhiukkaspäästöt ilmassa, liikahakkuut ja fossiilisen energian varaan rakennettu yhteiskuntajärjestys ovat muutamia esimerkkejä maapallon elonkehän tuhoamistendensseistä. Tuhoamme omankin elämämme edellytyksiä ja kuvaamme tällaista kehitykseksi, edistykseksi, talouskasvuksi, innovatiivisuudeksi, rohkeudeksi ja ennakkoluulottomuudeksi (ks. Sachs 1996). Kapitalismin, talouskasvun ja voitontavoittelun varaan rakennettu yhteiskunta on sosialisaatioympäristö ekologian suhteen välinpitämättö- 
mien kulutuskeskeisten halujen tuottamiselle, ei ekologiselle maailmassa olemiselle tai kohtuullistavalle "halujen kultivoinnille" (Värri 2018, 7175; Biesta 2019, 58-60; Orr 1992, 102).

Länsimainen kasvatus ja koulutus noudattelevat paljolti kognitiivisen psykologian ajatuksia, joissa lähdetään liikkeelle länsimaisen maailmankuvan oletuksesta, että ihminen on ympäristöstään erillinen olento (Järvilehto 1994; 2009). Koska ihminen on nähty luonnosta erillisenä ja sen yläpuolisena, hänelle on kuulunut oikeus käyttää luonnon "resursseja" hyödyksi haluamillaan tavoilla (Plumwood 2002; Shiva 1996). Luonnon vapaan hyödyntämisen ajatus, sen varaan rakennettu ihmiskäsitys sekä vapaaseen kuluttamiseen kasvatettu ihminen kuuluvat aikamme ekokriisien uusintamisen noidankehään. Individualistinen individuaation käsite, joka tarkoittaa minuuden kultivointia ja integrointia omaksi ainutlaatuiseksi kokonaisuudekseen varsin rajallisin muihin eläviin olentoihin kohdistuvin velvoituksin, sisältääkin ongelmia (Salminen \& Vadén 2018, 50-55; Salminen 2016). Individuaatio on ihmiskeskeisyydessään ongelmallisten humanististen perinteiden jatke (Salminen \& Vadén 2018, 55). Sen vuoksi vien tässä artikkelissa individuaation ajatusta ekologiseen ja ekososiaaliseen suuntaan ihmiskeskeisyyttä välttäen. Tarkasteluni lähtökohtana on kasvatusfilosofian perusjännite sosialisaation ja individuaation välillä (ks. Värri 2018, 16; Biesta 2009; Siljander 2002).

Sosialisaatio on yksilön kiinnittymistä yhteiskuntaelämään ja yhteisten tapojen omaksumista. Sosialisaatioympäristömme luo esimerkiksi mainonnan keinoin meille keinotekoisia haluja ja kannustaa elämäntapaan, joka ei ole erityisen kestävää (Brown 1995). Individuaatio puolestaan tarkoittaa psykologisessa mielessä vähittäistä psyykkistä prosessia, jonka myötä pieni lapsi kehittyy symbioottisesta tilasta itsetietoiseksi yksilöksi (Mahler, Pine \& Bergman 2002, 3-4). Alkujaan individuaatio tuli tunnetuksi jungilaisesta psykologiasta, jossa individuaatio on minuuden kultivointia ja integroitumista omaksi jakamattomaksi sekä ainutkertaiseksi kokemukseksi (Jung 1972, 267-268; Salminen \& Vadén 2018, 52-55; Schlamm 2014). Jungilainen individuaatio on eräänlaista totunnaisen egon korvautumista "korkeammalla itseydellä", mitä voi pitää länsimaisena vastineena itäiselle valaistumisen ajatukselle (Salminen 2016). Ekologisen individuaatiokäsityksen muotoilemisen helpottamiseksi en kuitenkaan rajaudu psykologien (Mahler ym. 2002, 3-4) tavoin varhaislapsuuteen enkä myöskään jungilaiseen psykologiaan (korkeammasta minästä ks. Pulkki 2020). Tässä artikkelissa puhun individuaatiosta laaja-alaisena 
kasvatusfilosofisena yleiskäsitteenä tarkoittaen prosessia, jossa kehitymme yksilöinä koko elämän ajan (Zoja 1997). Kasvatus on toimintaa, joka vaikuttaa individuaatioprosessin kulkuun.

Muotoilen artikkelissa uutta ymmärrystä individuaatiosta, jota kutsun ekoindividuaatioksi. Tarkoitan individuaatiolla ihmisen yksilölliseksi persoonaksi kehittymisen prosessia ja ainutlaatuisen elämänpolun kehkeytymistä (Damon 2006, 4). Individuaation käsite kattaa ihmisen ainutkertaisen yksilöllisen tajunnan, tunteiden ja tahdon laatujen muotoutumisen erilaisissa muodollisissa ja epämuodollisissa konteksteissa. Individuaation sijaan sosiaalipedagogiikassa käytetään usein personalisaation, identiteettitehtävän ja persoonaksi kasvamisen käsitteitä (esim. Kurki 2002; Nivala \& Ryynänen 2019; Harva 1968, 157-160; Siljander 2002). Kasvatusfilosofi Gert Biestan ajatukset subjektifikaatiosta ja subjektiudesta tulevat myös lähelle individuaation käsitettä ja ne tunnetaan laajalti (esim. 2019; 2020).

Näistä lähikäsitteistä subjektifikaatio ei sovellu tarkasteluuni, sillä se rajautuu eksistentiaalifilosofiaan eikä Biestan (2020) mukaan mahdollista esimerkiksi moraalista tarkastelua. Subjektifikaatio ei myöskään tarkoita tietyn subjektin ideaalin tavoittelemista. (Biesta 2020.)

Tutkimukseni lähtökohtana ovat ekologisia ongelmia uusintava kasvatusajattelu sekä erityisesti eliön ja ympäristön erottava individuaation ymmärrys, jotka näen ongelmallisiksi. Kehitys- ja ikäkausipsykologian esitykset tarkastelevat yksilöksi kehittymistä yleispiirteisesti empiirisen tutkimuksen pohjalta, mutta tässä tutkimuksessa tulokulma on filosofinen. Artikkelin tavoitteena on muotoilla ekoindividuaation käsitettä laaja-alaisena kasvatusfilosofisena (ontologis-fenomenologisena) yleiskäsitteenä, jonka avulla voi tarkastella ikiaikaisia kysymyksiä ihmisen ja muun luonnon suhteista, ihmisen paikasta maailmassa ja ihmisen oikeudesta luonnon (kohtuulliseen) hyödyntämiseen.

Ajattelen (eko)individuaatioprosessia tavalla, jossa ihminen on samaan aikaan ainutlaatuinen yksilö ja osa monilajisessa maailmassa ilman, että näiden välillä olisi välttämätöntä ristiriitaa. Lähtökohtani ei ole universaali vaan ihmisten, ympäristöjen ja kulttuurien erilaisuuksista johtuen paikallinen (ks. Vadén 2004; Vadén \& Hannula 2003). Yksilöllisen individuaatioprosessin tarkkarajaisen kuvauksen sijaan nojaan (Zeit Geist) kasvatusfilosofiseen aikalaisanalyysiin (ks. Saari, Jokisaari \& Värri 2014). Ekoindividuaatio on siinä mielessä perinteisen länsimaisen kasvatusfilosofian käsite, että sen mukaan kasvatukselle ja kehitykselle asetetaan päämääriä rakentaa ainutkertaista yksilöllisyyttä. Tavoitteeseen tulee kuitenkin pyr- 
kiä rakentavassa yhteistyössä monilajisen maailman kanssa. Artikkelissa hahmottelemani ekoindividuaatio ei ole ensisijaisesti moraalinen käsite, mutta siihen kuuluu sama moraalinen lähtökohta kuin ekososiaaliseen sivistykseen: tarve sovittaa ihmisen elämä yhden maapallon puitteisiin (ks. Salonen \& Bardy 2015).

Muotoilen ekoindividuaation ajatusta filosofis-monitieteisesti pyrkien korjaamaan organismin ja ympäristön erillisyyden ongelmaa etenkin ekopsykologian (Roszak 1993), systeemisen psykologian (Järvilehto 1994; 2009), ekofenomenologian (Salminen \& Vadén 2013) sekä syväekologian (Naess 2016; Macy 2014) virikkein. Artikkelin aluksi pohdin ekoindividuaation haasteen taustaa aatehistoriallisesti ja tarkastelen läntistä subjektifilosofiaa ja sen ihmiskeskeisyyttä. Esitän ekoindividuaation lähtökohdaksi eliön ja ympäristön erottamisen sijaan yhtä eliö-ympäristö-systeemiä (Järvilehto 1994). Länsimaisessa meritokraattisessa ajattelussa ihminen hankkii omilla ansioillaan oikeuden monenlaiseen omaisuuteen ja luonnon hyödyntämiseen. Ajatus ansioista kumpuaa kuitenkin osaltaan tavastamme erottaa ihminen ympäristöstään, jolloin ihminen ottaa ympäristöstä saamiaan asioita oman yksilöllisyytensä piiriin. Samaistumalla oman edun sijaan myös muiden eliöiden etuihin voidaan toteuttaa identifikaation syväekologista pedagogiikkaa niin sanotun ekologisen minuuden avulla. Lopuksi muotoilen asubjektiivisen kokemuksen valossa vaihtoehtoa nykyiselle individualistiselle individuaation ajatukselle eli ekoindividuaation idean.

\section{Ekoindividuaation haasteen aatehistoriallista taustaa ja läntisen subjektifilosofian kritiikkiä}

Ekologisoidun individuaation eli ekoindividuaation tarve nousee ihmiskeskeisyyden ongelmasta, eli antroposentrismistä. Antroposentrismin mukaan maailman tarkasteleminen ihmisen hyödyn näkökulmasta on oikeutettua ja velvollisuutemme rajautuvat ainoastaan ihmisiin (Taylor 1997, 225-226; White 1997). Moderni ihminen on luokitellut itsensä luonnosta erilliseksi ja luonnon yläpuoliseksi luomakunnan kruunuksi (Plumwood 2002). Luonto ja sen eliöt ovat resursseja ja raaka-aineita, joita ihminen ottaa haluamillaan tavoilla käyttöön (Shiva 1996; Salminen 2014).

Ajatus luonnon yläpuolella olemisesta liittyy keskiaikaiseen kristilliseen maailmankuvaan, jossa ihmisen paikka oli jumalasta ja hänen enkeleistään seuraavana (White 1997). Ennen modernia tieteen ja teknologian aikakautta monet "primitiivisiksi" leimatut kansat noudattivat eräänlaista 
alkemistien intuitiota: "niin ylhäällä kuin alhaalla". Tällaisessa ajattelutavassa ihminen on osa mikrokosmosta, josta on yhteys Äiti Maan, jumalien ja enkelten makrokosmokseen. (Roszak 1993, 15-16; ks. Merchant 1983.) Moderniin maailmaan tultaessa siteet ihmisen mikrokosmoksen ja korkeamman makrokosmisen todellisuuden välillä katkesivat.

Descartesin mieli-aine-dualismi, tieteellinen vallankumous sekä jumalkeskeisen maailmankuvan vähittäinen sortuminen maallis-mekanistisen maailmanymmärryksen tieltä rakensivat kuvaa minuudesta, joka on subjektin sisällä, ja maailmasta, joka on sen ulkopuolella. Tieteellisen vallankumouksen myötä ulkomaailmasta tuli varman ja objektiivisen tiedon kohde, makrokosmos. Ihmisen sisäisyys, mikrokosmos, jäi unien, tunteiden ja hallusinaatioiden subjektiiviseksi hetteiköksi. Subjektiivisuus ja objektiivisuus erosivat toisistaan, ja esimoderni yhteydenpito mikroja makrokosmosten välillä tukahtui. (Roszak 1993, 15-16; ks. Merchant 1983; Orr 1994, 133; Abram 1996.)

Filosofit Antti Salminen ja Tere Vadén tarjoavat ekofenomenologisen ja ontologisen perspektiivin nykysubjektin rakentumiseen ja kritiikkiin: fossiilisubjektin. Heidän Energia ja kokemus -teoksensa (2013) kuvaa, kuinka fossiilisen energian käyttöönotto 1800-1900-luvuilla muutti tapaamme kokea ihmisen paikka maailmassa sekä omat mahdollisuutemme maailman muuttajina. Fossiilisella energialla elähdytetty tuotantokoneisto, jonka taustalla oli tieteen, teknologian ja teollisuuden kehitys, on olennainen osa nykyaikaisen kulutuskulttuurin ja subjektiviteetin rakentumista. Fossiilisesta energiasta ei rakentunut vain elämäntapamme energeettinen perusta vaan myös erityinen inhimillisen kokemuksellisuuden laatu. Raskas fyysinen työ tuli fossiilisen energian, tieteen ja teknologian myötä pitkälti voitetuksi. (Salminen \& Vadén 2013.)

Fossiilienergian käyttöönoton mukanaan tuomia toimintamahdollisuuksia seurasi vallankumouksellinen kokemuslaatu: voimme tehdä melkein mitä tahansa. Tämä ajatus yhdistettynä käsitykseen ihmisestä muusta luonnosta erillisenä luonnon hallitsijana luo perustan subjektin hybrikselle eli röyhkeydelle ja ylimielisyydelle. Samalla, kun fossiilinen energia mahdollisti mitä uskomattomampien projektien toteuttamisen, homogeenisen energian alkuperä jäi ihmiselle kokemuksellisesti vieraaksi. Ihmisestä tuli moderni, vapaa ja kulutuskeskeinen subjekti siksi, että kokemuksellisesti vieras (fossiili) energia tekee työtä puolestamme. Ihmiskeskeinen käsitys subjektin vallasta ja vapaudesta tehdä mitä hyvänsä luonnon "resursseille" (objekteille) onkin sisäänrakennettu länsimaisen 
subjektin ajatukseen. (Salminen \& Vadén 2013; 2018.) Myös individuaatioprosessissa ihminen ajatellaan dekontekstualisoidusti ympäristöistä irrallaan ymmärtämättä sitä, kuinka ihmiselämä on riippuvainen suuresta määrästä muita eliöitä (Järvilehto 1994).

Ekoindividuaation käsitteelle ja kasvatusfilosofialle on tarvetta siis länsimaisen subjektikäsityksen ongelmien vuoksi. Ihmiskeskeisyys ja ihmisen hyödyn näkökulman nostaminen ensisijaiseksi on tehnyt muista elävistä olennoista hyödynnettäviä resursseja, joiden hyvinvoinnista ei tarvitse välittää. Ihmiskeskeisyyden vuoksi meillä on mielestämme velvollisuuksia vain ihmisiä eikä monilajista maailmaa kohtaan. Kun lisäksi ihminen on ajateltu muuta luontoa paremmaksi ja luonnosta irralliseksi fossiilisubjektiksi, joka ei tunnista toimintansa perustumista fossiilienergiaan, ihmiselle on kehittynyt runsaasti valtaa vailla vastuuta tai velvoituksia. Tällainen yksilöllisyys heijastuu aikamme individuaation tapoihin ja prosesseihin. Ennen ratkaisuksi tähän hahmottelemani ekoindividuaation tarkempaa muotoilua, tarkastelen kuitenkin individuaation ja sosialisaation yleispiirteitä ja sijoitan ne monilajisen maailman kontekstiin.

\section{Individuaation ja sosialisaation sijoittaminen monilajisen maailman kontekstiin}

Kasvatus on ytimeltään sosialisaation pedagogista ohjaamista, jotta yksilöstä tulisi yhteiskunnan toimintakykyinen jäsen, sekä yksilökehityksen (individuaatio) edistämistä, jotta ihminen löytäisi ainutlaatuisen persoonallisen identiteettinsä ja elämänpolkunsa (Biesta 2020; Antikainen 1993, 75-98; Ruitenberg 2013, 91). Kasvatuksen näkökulmasta yksilöksi kehittyminen ja yhteiskunnan jäseneksi kehittyminen ovat saman kasvuprosessin aspekteja (Rorty 1999, 117). Sosialisaatioparadoksin käsitteellä tunnetaan ajatus, jonka mukaan kasvatus kohdistuu olemassa olevan sosiaalisen maailman pelisääntöjen oppimiseen ja samanaikaisesti niiden kyseenalaistamiseen ja muuttamiseen (Damon 2006; Siljander 2002, 46).

Sosialisaation perusongelmana on ollut ihmiskeskeisyys. Uusi ekososialisaation käsite (Keto \& Foster 2021) on hyvä esimerkki tieteessä ja muuallakin käynnissä olevasta ekologisesta käänteestä, jonka myötä ihmisen asema maapallon suvereenina valtiaana asettuu kyseenalaiseksi. Ekologisen käänteen myötä ihmisen tarkasteluun tulevat ekososiaaliset suhteet muihin eliöihin ja ekosysteemeihin sekä ihmisen riippuvuus elämää kannattelevien järjestelmien elinvoimaisuudesta ja terveydestä. Ekososiaalisaatio on sosialisaatiolle rinnakkainen käsite, jonka mukaan 
ihminen oppii ihmisten maailman tapojen lisäksi monilajisen maailman tavoille ihminen-ekosysteemi-interaktioissa. (Keto \& Foster 2021.)

Eko-etuliite ekoindividuaation ja ekososialisaation käsitteisiin tulee ekologiatieteestä, joka tutkii eliöiden ja näiden ympäristöjen vuorovaikutteisia suhteita ja keskinäisriippuvuuksia (esim. Scheiner \& Willig 2008). Ekososialisaation moraalisena lähtökohtana on tarve korjata ihmiskunnan ekologinen tuhoavuus siten, että koemme vastuuta ihmisten lisäksi myös muista eliöistä ja ekosysteemin toimivuudesta, joihin ihmisen toiminta nykyisin vaikuttaa (Keto \& Foster 2021).

Ihmisen tarkastelu ympäristöstä irrallaan olevana oliona on ollut syynä moniin ihmisen toiminnan ymmärtämisen ja selittämisen vaikeuksiin. Nämä vaikeudet ovat osittain syynä myös käytännön ekologisiin ongelmiin, joita ihmisen taloudellis-tekninen toiminta on tuottanut. Aiemmin tarkastelemani länsimainen tapa asettaa ihminen luonnon yläpuolelle on Järvilehdon (1994) mukaan omaksuttu myös psykologiatieteen lähtökohdaksi. Kyseessä ei ole tieteellinen totuus vaan arvosidonnainen jako yhtäältä rationaalisesti ajattelevaan ja autonomiseen ihmiseen sekä toisaalta uhkaavaan, karkeaan, alkeelliseen ja epätäydelliseen luontoon. Ympäristö ja luonto on nähty paitsi ihmisen ulkopuolisiksi asioiksi ja myös ihmisen sisäistä maailmaa häiritseviksi ärsykkeiksi. (Järvilehto 1994, 16-22; myös Roszak 1993.)

Ekososialisaatiolle ja ekoindividuaatiolle on yhteistä pyrkimys kontekstoida sosialisaatio- ja individuaatioprosessit monilajisiin yhteisöihin ja ekosysteemeihin, joita ei ymmärretä ihmisen ulkopuolisina häiritsevien ärsykkeiden kokoelmana vaan ihmisenkin elämän uusintamisessa tarvittavana itseisarvona. Ekoindividuaatio samoin kuin ekososialisaatio lähtee liikkeelle syväekologisesta arvolähtökohdasta: elämän tuhoaminen on väärin (esim. Naess 2016). Jotta elämän suojelu olisi mahdollista, on purettava perinteisen individuaation ongelmana oleva lähtökohtaoletus organismin ja sen ympäristön erillisyydestä.

\section{Eliö-ympäristö-systeemi ja oikeutuksentunnon ongelma}

Systeemisen psykologian lähtökohta on ajatella ihmistä (organismia) ja tämän ympäristöä kahden sijasta yhtenä systeeminä. Ihmisen järki, ajatukset, tahto ja muut länsimaisen maailmankuvan ja kognitiivisen psykologian korostamat seikat ovat osa samaa ihmisen ja tämän ympäristön kattavaa systeemiä. Eliön ja ympäristön yhteenkuuluvuudesta onkin puhuttu jo 1800-luvulla, ja edelleen tarkkaa rajaa eliön ja ympäristön välille 
on vaikea määritellä. Milloin esimerkiksi hengitetty ilma on sisäilmaa ja milloin ulkoilmaa? Ihminen hengittää sisään puiden tuottamaa happea ja ulos hiilidioksidia, jota puu tarvitsee kasvamiseensa. Miksi nämä olisivat erillisiä asioita? Entä onko iho absoluuttinen ihmisen ja ympäristön raja? Eivätkö ihokarvat ole osa ihmisen elimistöä ihon ulkopuolella? Ihosolut ovat jatkuvassa aineenvaihdunnassa ympäristönsä kanssa, eikä edes yksittäistä ihosolua voi määritellä irrallaan ympäristöstään, sillä solun aineenvaihduntajärjestelmä muodostuu solun ja tämän ympäristön osista. (Järvilehto 1994, 23-33.)

Ekoindividuaation ajatus lähtee systeemisen psykologian yhden eliöympäristö-järjestelmän ajatuksesta kahden erillisen järjestelmän sijaan. Ihmisen tarkastelu yhtenä eliö-ympäristö-systeeminä ei ole kuitenkaan yksinkertaista, koska keskinäisriippuvuudet eliön ja ympäristön välillä ovat monimutkaisia. Tieteellisen tiedon tavoittelu ja älyllisen fokusoinnin pyrkimys ovat johtaneet pelkistäviin ja osittaisiin kuvauksiin, joissa organismi nähdään dualistisesti ympäristösuhteistaan irrallaan. Länsimaisessa maailmankuvassa on runsaasti muitakin dualistisia jännitteitä, jotka voivat haitata ekoindividuaation ajattelemista: ihmisen kulttuuri on nähty erillään luonnosta, järki erillään tunteesta, subjekti erillään objektista ja niin edelleen (Roszak 1993, 16). Eko-oikeudenmukaisuuskasvatus (ecojustice education) on ottanut tehtäväkseen näiden hierarkkisten dualismien purkamisen, jotta ekologisella ajattelulla ja siihen liittyvällä kasvatuksella olisi paremmat toimintamahdollisuudet (Martusewicz, Edmundson \& Lupinacci 2015).

Keskeinen dualismi, jonka vuoksi yhteen eliö-ympäristö-systeemiin perustuvan ekoindividuaation ajatteleminen on vaikeaa, koskee yksilöä ja yhteiskuntaa. Tämä kahtiajako juontaa juurensa ainakin liberaaliin filosofiaan, moderniin yhteiskuntasopimusteoriaan sekä taloustieteeseen. Modernit kansallisvaltiot rakennettiin yksityisomaisuuden turvaamista varten, ja modernia ihmiskuvaa voidaan kutsua omistusindividualismin nimityksellä (possessive individualism, Macpherson 1962; ks. Locke 1995). Valtion tehtäväksi tuli yksilön vapauden ja omistusten turvaaminen, mutta vapausajatuksiin liittyy aggressiivisia oletuksia. Hobbesilaisessa ihmiskuvassa ihmisen loputtomat halut ja toiveet johtavat niukkuuteen, josta seuraa aina kuolemaan asti jatkuvaa valtataistelua ja kilpailua (Hobbes 1985; Pulkki 2017). Valtavirran taloustiede otti 1800-luvun lopulla omakseen loputtomasti haluavan ja tarvitsevan ihmisen sekä näistä seuraavan niukkuuden ja kilpailun lähtökohdat (Marglin 2009; Pulkki 2017). 
Tällainen kilpailua ja taistelua painottava ajattelutapa, josta on tullut modernin länsimaisen ihmisen maailmankuvan eräs peruslähtökohta, sopi aikansa koulutettujen, valkoisten ja kristittyjen miesten kolonialistiseen projektiin, johon sovitettiin myös ajatus evoluutiosta olemassaolon taisteluna (Montagu 1952). Systeemiteoriaa tutkinut syväekologi Joanna Macy kritisoi länsimaista kilpailukeskeistä subjektifilosofiaa sellaisiin pako- ja taistelustrategioihin jumiin jäämisestä, joissa minuus on hypoteettinen reviiri ja sitä on jatkuvasti puolustettava (Macy 2009, 183-193). Erillinen minä on Macyn (2009) mukaan heiveröinen rakennelma, jonka puolustaminen syö sen voimia ja estää avautumista muulle elämälle.

Keskeinen eliön ja ympäristön erottamisesta seuraava ongelma, johon voidaan yhden eliö-ympäristö-systeemin kautta etsiä parannusta, on eräänlainen oikeutuksentunto (sense of entitlement, Pulkki 2017, 36). Ajatus luonnosta resursseina sisältää ajatuksen siitä, että meillä on oikeus sen hyödyntämiseen (Shiva 1996). Länsimainen ympäristöstään erillinen yksilö kokee olevansa oikeutettu kaikkeen työllä ja vaivannäöllä hankkimaansa (ks. Locke 1995). Omistusindividualistinen yksilö vieläpä identifioituu siihen, mitä hän omistaa. Ihminen eräässä mielessä on yhtä kuin omistuksensa, joihin myös hänen ansionsa kuuluvat (ks. Fromm 1993; 1977).

Eliön ja ympäristön erottamisen seurauksena tunnistamme kehnosti asioita, joista olemme velkaa ympäristöllemme. Emme kasvaisi aikuisiksi ilman monen ihmisen mittavaa vaivannäköä ja kasvatusta. Ajatus eliön ja ympäristön irrallisuudesta onkin johtanut siihen, että fossiilisen ja muunkaltaisen ylimääräisen energian osuutta omissa toimissa ei tunnisteta, vaan siitä tulee osa omaa ansiota. Eliön ja ympäristön erottelun puitteissa yksilö ottaa omakseen eli omii muiden henkilöiden ja (fossiili)energian panostuksia, ja tekee näistä omia ansioitaan.

Jos irrallisuuden sijaan eliö ja ympäristö nähdään yhtenä systeeminä, ansiotkin aletaan nähdä yhdessä yksilön ominaisuuksien ja yksilön toimeliaisuutta mahdollistavien ympäristötekijöiden kanssa. Yhden eliöympäristö-systeemin ajatuksen valossa nykyaikaiseen yksilökehitykseen liittyvä oikeutuksentunto voi asettua kohtuullisempaan valoon. Ihmisen ymmärtäminen ympäristönsä kanssa yhtenä systeeminä mahdollistaa hyve-eettisesti ajatellen kiitollisemman ekoindividuaation ja luo perustaa kiitollisemman mielenlaadun omaksumiselle. Ehkä emme tarvitse minuutta hypoteettisena reviirinä, jota puolustaa (Macy 2009, 183-193), vaan minuuden rajat voivat olla joustavampia, kuten asubjektiivisen kokemuslaadun yhteydessä ehdotan. 
Systeemiteoriaan viitaten Macy sanookin, että ei ole olemassa kategorista minää, jolle ulkomaailma olisi paettava tai taisteltava vastustaja. Tällainen taistelun ja pakenemisen valossa tulkittava minä on ajatusrakennelma, jonka voidaan ajatella koskevan omaa nahkaamme, persoonaamme, perhettämme, organisaatiotamme tai lajiamme. Minää voidaankin harjoittaa ja laajentaa esimerkiksi kuvittelukyvyn ja meditatiivisten harjoitusten avulla. Macy korostaa ekoindividuaatiota valottavalla tavalla rakkauden merkitystä ja harjoittamista. (Macy 2009, 154-168, 187-192; Pulkki, Saari \& Dahlin 2015; ks. Brown 1995.)

\section{Ekologinen minuus ja identifikaation syväekologinen pedagogiikka}

Syväekologi Arne Naessin (1912-2009) ekologisen minuuden ajatus on kiinnostava ekoindividuaation muotoilun kannalta. Ekologinen minuus mahdollistaa joustavamman, vähemmän kilpailukeskeisen ja oikeutuksentuntoisen sekä paremmin yhteistyöhön ja jakamiseen soveltuvan subjektin. Naess muotoili ekologisen minuuden ajatuksen ensi kerran Self-Realization: An Ecological Approach to Being in the World -artikkelissaan vuonna 1987 (sisältyy teokseen Ecology of Wisdom, Naess 2016). Hän tiivistää artikkelinsa kuuteen ydinkohtaan, joissa muotoillaan ekologista minuutta ja siihen liittyvää ajattelua. Seuraavassa esitän listan edelleen tiivistetyssä muodossa, koska se on avuksi myös ekoindividuaation muotoilussa:

1. Aliarvioimme itsemme ja minuutemme sekoittamalla toisiinsa aidon minuuden ja kapean egon.

2. Perusteellisesti ja monipuolisesti kypsynyt ihminen identifioituu väistämättä muihin eläviin olentoihin.

3. Perinteisesti minuuden kypsyyden on ajateltu kehittyvän kolmivaiheisesti: egosta sosiaaliseen minuuteen (sisältäen egon) ja sosiaalisesta minästä transsendentaaliseen minään (sisältäen sosiaalisen minän). Ongelmana tässä maturiteetin ymmärryksessä on, että muut elävät olennot kuin ihmiset sekä identifioituminen näihin on sivuutettu. Koska muut elävät olennot on suljettu pois ihmisen minuudesta, Naess esittää alustavan ekologisen minuuden ajatuksen, jossa minä nähdään rikkaampana konstitutiivisissa suhteissaan monenlaisiin eläviin olentoihin. Yhteisökäsitys ekologisessa minuudessa on monilajinen yhteisö (mixed community). 
4. Ihmisen onnellisuus ja elämän mielekkyys lisääntyy itseoivallusten (self-realization) myötä. Itseoivallukset ovat eri ihmisillä erilaisia, mutta itseoivallus viittaa minuuden laajenemiseen ja syvenemiseen.

5. Minuuden kypsymisen myötä tapahtuva väistämätön identifikaatio toisiin eläviin olentoihin tarkoittaa minuuden syvenemistä ja laajenemista siten, että "näemme itsemme toisissa".

6. Ekologisen tuhon välttäminen aiheuttaa haasteensa kaikkien elävien olentojen hyvän elämän mahdollisuuksille. (Naess 2016, 81-82; Wang 2016, 1258-1259.)

Ekologisen minuuden ajatuksessa ihmisen (ontologista) irrallisuutta muista eliöistä ja luonnosta sekä kuvitelmaa oikeudesta luonnon pidäkkeettömään hyödyntämiseen voidaan kasvatuksellisesti vähentää identifikaation laajentamisen ja sitä seuraavien itseoivallusten avulla. Itseoivallukset eivät ole ympäristöstä erillisen individualistisen minän oivalluksia vaan koskevat minuuden laajentamista siten, että osaamme samaistua erilaisten olentojen asemaan. Tätä samaistumista voidaan kuvata John Seedin esimerkkin avulla. Puolustaessaan Australian sademetsiä Seed piti mielessään, että "tässä ei ole kyse minusta. [...] Minä olen se osa sademetsää, joka on hiljattain ilmaantunut ihmisen ajatteluun". Seed on myös puhunut "hengellisestä muutoksesta", jossa minän ja ei-minän tai itsen ja luonnon erillisyys, vieraantuneisuus, poistuu syvällisessä yhteenkuuluvuuden tunteessa kaiken elollisen kanssa. Seedin esimerkki kuvaa myös sitä, mitä Naess tarkoitti laajentuvalla ja syventyvällä samaistumisella. Itsensä sademetsän osaksi kokeva ihminen haluaa hakata sademetsän osapuilleen yhtä paljon kuin sahata omaa jalkaansa. Ekologisen minän kokemusmaailma siis muuttuu, mikä johtaa parhaimmillaan "pitkäjänteiseen ja sitkeään toimintaan elämän säilymisen puolesta”. (Macy 2009, 184-186; Naess 2016; ks. Seed, Macy, Fleming \& Naess 1988.)

Ekologisessa minuudessa ei ole kyse itsensä, onnellisuutensa ja hyvinvointinsa suuremman hyvän eteen uhraavasta sankariyksilöstä, mikä voi olla toimiva ajatusmalli lähinnä erityistilanteissa (Naess 2016). Naess tarkastelee ekologista minuutta ontologisesti ja näkee moralisoivan lähestymistavan ongelmallisena, sillä se aiheuttaa usein luotaan työntävää häpeää ja syyllisyyttä. Filosofi Erich Frommin (1900-1980) ajatteluun tukeutuen Naess toteaa ympäristöaktivismin ja länsimaisen individualismin ongelmaksi jyrkän vastakkainasettelun itsekkyyden ja epäitsekkyyden välillä. Itsekkyys tuomitaan, ja epäitsekkyys sekä omien etujen uhraaminen näh- 
dään hyveellisenä. Kun jyrkkää eroa minän ja maailman tai muiden ihmisten välillä ei tehdä, myöskään uhrautumisen ja menetyksen tunteita ei kehity tai kehittyessään ne eivät ole pitkäkestoisia. (Naess 2016; 81-96; Fromm 1986, 119-140; Macy 2009, 193.) Häpeän, moraalisen paheksunnan ja tuomitsemisen sijaan ekoindividuaatiota voidaan ajatella Naessin (2016, 81-96) tavoin omaa kapeaa minuutta laajemman käsityskyvyn tuottaman ilon ja tästä seuraavan välittämisen näkökulmasta. Naessin mukaan muihin eliöihin samaistuva ja yhteisyydestä näihin nauttiva ihminen myös välittää luontaisesti ja aistillisesti muista elävistä olennoista ilman velvollisuudentunnon raskautta.

Ekologiselle minälle maailma on osa itseä ja itse on osa maailmaa, kuten systeemisessä psykologiassa. Alkuperäiskansat ovat ympäri maailman nähneet minuuden maailman osana, joten minän ja maailman ero on vähemmän jyrkkä kuin mihin olemme tottuneet. Voisi otaksua, että minän suhde maailmaan on tällöin myös lempeämpi. Koska olioiden välillä on prosessimainen vuorovaikutus ja keskinäisriippuvuus, ei yksilöllisyyskään ole ontologista erillisyyttä. (Macy 2009, 19-36; ks. Abram 1996.) Vähemmän puolustusta vaativia kokemuslaatuja, joissa minuuden rajat ovat joustavia, on olemassa (Vadén \& Torvinen 2014). Seuraavassa luvussa pohdin asubjektiivisen kokemuksen käsitteen avulla vähemmän oikeutuksentuntoisen, kilpailullisen, omistuksellisen ja enemmän jakamiskykyisen subjektin sekä tähän liittyvän kasvatusajattelun mahdollisuutta.

\section{Asubjektiivinen kokemus}

Asubjektiivinen kokemus kumpuaa länsimaisen subjektifilosofian kritiikistä sekä vaihtoehtoisesta (ei modernista) tavasta kokea maailma sitä objektivoimatta (Salminen 2016). Vadénin $(2004,50 ; 2000,70)$ ja Salmisen $(2015,54-55)$ mukaan asubjektiivisuus tulee sanasta subjektiivinen ja tämän kieltävästä a-etuliitteestä tarkoittaen subjektia ja objektia erottamatonta kokemuslaatua. Sana asubjektiivinen ei kuitenkaan viittaa objektiivista tietoa korostavaan ja "vain subjektiivista" kokemuksellisuutta väheksyvään ajattelutapaan, kuten satunnaisiin tunteisiin, ajatuksiin ja tahtomuksiin. Asubjektiivisuuden ymmärtämiseksi on olennaista tunnistaa subjektiin ja objektiin liittyviä rakenteita, joihin liittyy ajatuksia, objekteja ja persoonia. Tässä rakenteen mielessä subjektius on universaali ja kaikkien subjektien jakama sekä kaikkia subjekteja samoihin suuntiin ohjaava ilmiö. A-subjektiivinen siis edeltää subjektin ja objektin erottamista, ja se on ekologisesti problemaattisen modernin kulttuurin 
rakenteista riippumaton kokemuslaatu. (Vadén \& Torvinen 2014; Vadén \& Hannula 2003.)

Filosofi Pauli Pylkkö (1998) ottaa asubjektiivisen kokemuslaadun esimerkiksi suomen kielessä esiintyvän "epäpassiivi"-sanan "ollaan", jossa ei ole yksilösubjektia. Indoeurooppalaisista kielistä tällaista subjektitonta sanaa ei löydy, eikä sitä voi näille kielille kääntää. Aiemmin mainitun omistusindividualismin kannalta on kiinnostavaa, että koko moderni kansallisvaltio on Pylkön mukaan alkuperäiskansojen elämäntapoihin suhteessa kolonialistinen projekti, joka myös uhkaa suomen kielen asubjektiivisia (alkuperäiskansaisia) merkitysvarantoja. Moderni kansallisvaltio ja sen omistava subjekti lähtee liikkeelle ihmisestä, jolle maailma on hyödyntämisen, käytön ja omistamisen objekti. Vaikka moderni kansallisvaltio sekä subjektia ja objektia erottavien kielien yleistyminen uhkaa asubjektiivista kokemustamme, sen merkitysvarantoja ei vielä ole kokonaan menetetty. Yhä on mahdollista kokea maailmaa suomeksi ilman subjekti-objekti-erottelua, subjekti-subjekti-erottelua tai subjekti-ei-subjekti-erottelua. (Pylkkö 1998; Salminen \& Vadén 2018, 55-62.) Maailma voi vieläkin olla jotain muuta kuin hallinnan, käytön ja omistamisen kohde.

Suomalainen subjektia ja objektia erottamaton kielenkäyttötapa on ekoindividuaation kannalta kiinnostava juuri siksi, että se uhmaa länsimaista objekteihin suuntautuvaa ja itsensä muista erottavaa subjektia sekä individualismia omalla ennakoimattomuudellaan, erottelemattomuudellaan ja hallinnan ulottumattomissa olemisellaan (Pylkkö 1998). Asubjektiiviset kokemukset uhmaavat myös subjektin muureja, jotka se on rakentanut suojelemaan omaa maailmasta erottautumistaan. Kokemukset eivät ole yksinkertaisesti Minun tai Sinun, vaan kokemusten keskus, subjekti, on asubjektiivisessa kokemuksessa joustava ja mukautuva. (Vadén 2000, 70; Salminen \& Vadén 2018, 57-62; Pylkkö 1998.)

Vadénin $(2016,135)$ mukaan subjekti tarkoittaa "ajattelun, kokemisen ja toiminnan tekijää, jonka voidaan katsoa säilyvän samana ajanhetkestä toiseen ja jota voidaan pitää esimerkiksi vastuullisena teoistaan." Subjektin pysyvyys ja Macyn kuvaamat minän puolustettavat rajat kuitenkin vastustavat perusteellista uusiutumista. Tämän vuoksi tarvitaan asubjektiivista kokemuksellisuutta, joka purkaa minän rajoista ja niihin liittyvistä kulutusmahdollisuuksista ja vapauksista kiinnipitävää minuutta. Koska subjektin päämäärä on lisätä yksilöllisen vapauden asteita, tämän on järjellistä vastustaa luonnon tuhon estämiseen kohdistuvia toimia. Asubjek- 
tiivisuus onkin reittivalinta kohti kasvavaa länsimaisen subjektin purkautumista, eikä vain kohti lisääntyvää järkeä. (Vadén 2016, 135.)

Asubjektiivinen on länsimaisen, hallintasuuntautuneen, omistavan, manipulatiivisen, teknologisen ja maailmasta erottautuneen subjektin vaihtoehto. Radikaalisti kapinallisen subjektin tuottaminen ei riitä, kun subjektin kokemuksellinen perusrakenne on olennainen osa itse ekologista problematiikkaa. (Salminen 2015, 54-55; Vadén 2004, 50; 2000, 70.) Kapinallinen subjektikin pitää itseään muusta luonnosta irrallisena ja näkee luonnon objektina, käyttökohteena ja resurssina.

Asubjektiivisuus liittyy myös alkuperäiskansaistumiseen (Vadén 2010). Moderneista länsimaisista yhteiskunnista ei ole tavattu esimerkkejä ekologisesti kestävistä elämäntavoista, mutta alkuperäiskansoista näitä löytyy (Vadén 2010, 34-35, 61-67). Tämä ei tarkoita menneisyyteen paluuta ja kaiken teknologian hylkäämistä, vaan se tarkoittaa ekologisesti kypsistä elämäntavoista oppia ottamista, yhden maapallon luonnonvaroilla toimeen tulemista ja näitä mahdollistavan yksilökehityksen prosessin kasvatuksellista mahdollistamista. Ekoindividuaatioon pyrkivässä kasvatuksessa onkin tärkeä luoda mahdollisuuksia ja tilaisuuksia asubjektiivisten kokemusten esiintymiselle: tylsyys (tai vähävirikkeisyys), rakkaus, hoiva, meditaatio ja taide ovat esimerkkejä arjen tilanteista, joissa kokemustamme voidaan sanoa asubjektiiviseksi ja koemme maailman ilman subjektiobjekti-erotusta (Vadén \& Hannula 2003, 57-60; ks. Macy 2009).

\section{Lopuksi: kohti ekoindividuaation ekososiaalista kasvatusfilosofiaa}

Ekoindividuaatio kuvaa ekologisesti kestävää ainutkertaiseksi yksilöksi kehittymisen ja kasvun ajatusta. Ihminen ja ympäristö eivät ole kaksi eri asiaa vaan yhden saman systeemin keskinäisriippuvaisia aspekteja (Järvilehto 1994; 2009). Kun ihmis-subjekti on nähty erillisenä luonto-objektista, luonnosta on pahimmillaan tullut voitettava vastus ja vihollinen, joka on kesytettävä ja alistettava ihmisen tahtoon (ks. Achterhuis 1993). Länsimainen koulutus vaikuttaa vahvistavan subjektin ja ei-subjektin sekä subjektin ja objektin raja-aitoja. Koulutuksen ei kuitenkaan ole pakko toimia vain tiedetyn, varman, käsitteellistetyn, hallitun ja hyödyllisen alueilla (ks. Gomes \& Kanner 1995: Vadén 2010). Monet kasvatusajattelijat (esim. Rousseau 1905) ovat korostaneet esimerkiksi omakohtaista aistien käyttöä, myös sellaisilla alueilla, joiden käsitteellinen haltuunotto on hankalaa (ks. Sewall 1995). 
Ekoindividuaatio on korjausliike liberaalille individualismille, joka korostaa oikeutuksentuntoisesti yksilön oikeuksia yhteisöllisten ja ekososiaalisten velvollisuuksien kustannuksella. Ekoindividuaatio tarkoittaa täydempää kollektiivisten velvoitteiden täyttymistä, ja yksilöllisten erikoislaatujen kasvatuksellinen edistäminen mahdollistaa paremmin sosiaalisuuden kuin niiden tukahduttaminen tai sivuuttaminen. Perinteinen individuaatio on ihmiskeskeinen ja humanistinen ajattelutapa, mutta ekoindividuaatiossa kollektiivisuus ei ole ihmiskeskeistä vaan monilajisuuteen kiinnittyvä ajatus. Ihmisen tulee liittyä monilajiseen maailmaan ymmärtävällä, lempeällä, arvostavalla ja yhteistä maailmaa luovalla tavalla.

Ekoindividuaation käsite mahdollistaa kasvatuksen ajattelun ekologisesti kestävämmän yksilönkehityksen näkökulmasta. Keskeistä on ohjata yksilönkehityksen prosessia tavalla, joka ei edellytä sankarillista uhrautumismentaliteettia tai ekofasismiin kallistuvaa itsekielteisyyttä (ks. Naess 2016). Ekoindividuaation kannalta on olennaista, että Naessin (2016) mukaan itsetoteutusta voidaan tehdä ei-konsumeristisella ja elonkirjosta iloa ammentavalla tavalla. Samaistuessamme ihmisyksilön etunäkökohtia laajemmalle (Macy 2014; Naess 2016), koemme myös mielihyvää asubjektiivisella tavalla monenlaisten elävien olentojen kukoistuksesta.

Ekoindividuaatio sisältää subjektiivista ja asubjektiivista kokemuksellisuutta. Onnistuneen ekoindividuaation myötä ihminen ei halua aiheuttaa haittaa muille eläville olennoille, sillä tämä aiheuttaa kärsimystä ihmiselle itselleenkin. Länsimainen subjekti on valinnut erottautumisen muista elävistä olennoista ja näiden kärsimyksestä. Asubjektiivisen kokemuksen kautta voimme ehkä kokea muiden olentojen kärsimyksen ja saada syitä välttää sitä monilajisessa kodissamme.

Ekoindividuaatio asubjektiivisen kokemuksen avulla ymmärrettynä ei tarkoita egon tuhoa. Individuaatio tähtää päinvastoin juuri sellaisen ekologisen minuuden rakentamiseen, jossa minä asettuu monilajisen maailman jäsenyyteen ilman herruuspyrintöjä ja tuntoa oikeutuksesta luonnon loputtomaan kestämättömään käyttöön. Asubjektiivisen kokemuksen myötä minuuden herruus tajunnan merkityksellistäjänä ja napana kirpoaa (Salminen \& Vadén 2018, 51-53), jolloin myös monipuolisempi ja herkempi elämän havainnointi tulee mahdollisemmaksi. Ekoindividuaatio säilyttää kielenkäyttöömme sisältyvän asubjektiivisen kokemusmahdollisuuden ja ruokkii tätä. Ihmisen minä tietysti säilyy, mutta siihen liittyy kognitiivista joustavuutta. Asubjektiivinen kokemuslaatu ei tule itsestään, mutta esimerkiksi haltioituneessa luontokokemuksessa, 
taide-elämyksissä ja meditaatiossa se voidaan saavuttaa (Vadén 2004, 51; Vadén \& Torvinen 2014; ks. Macy 2014; 154-157).

\section{LÄHTEET}

Abram, D. 1996. The Spell of the Sensuous: Perception and Language in a More-ThanHuman World. New York: Vintage Books.

Achterhuis, H. 1993. Scarcity and Sustainability. Teoksessa W. Sachs (ed.) Global Ecology. A New Arena of Political Conflict. London \& New Jersey: Zed books, 104-116.

Antikainen, A. 1993. Kasvatus, koulutus ja yhteiskunta. Helsinki: WSOY.

Biesta, G. 2009. On the Weakness of Education. Teoksessa D. Kerdeman (ed.) Philosophy of education. Urbana, IL: Philosophy of Education society, 354-362. Saatavissa http:// hdl.handle.net/1893/7445 (haettu 31.8.2021).

Biesta, G. 2019. What is the Educational Task? Arousing the Desire for Wanting to Exist in the World in a Grown-up Way. Pedagogia y Saberes 50, 51-61.

Biesta, G. 2020. Risking Ourselves in Education: Qualification, Socialization, and Subjectification revisited. Educational Theory 70 (1), 89-104. DOI: https://doi. org/10.1111/edth.12411.

Brown, L. 1995. Ecopsychology and the Environmental Revolution: An Environmental Foreword. Teoksessa M. E. Gomes \& A. D. Kanner (eds.) Ecopsyschology. Restoring the Earth, Healing the Mind. San Francisco: Sierra Club Books, xiii-xvi.

Damon, W. 2006. Socialization and Individuation. Teoksessa G. Handel (ed.) Childhood Socialization. Second edition. New Brunswick: Aldine Transaction, 3-9.

Fromm, E. 1977. Olla vai omistaa. Suom. M. Kannosto. Helsinki: Kirjayhtymä.

Fromm, E. 1986. Man for Himself. An Inquiry into the Psychology of Ethics. London: Ark.

Fromm, E. 1993. Omistamisesta olemiseen. Itsetiedostuksen teitä ja harhapolkuja. Suom. M. Arppo. Helsinki: Kirjayhtymä.

Gomes, M. E. \& Kanner, A. D. 1995. The Rape of the Well-Maidens. Feminist Psyschology and the Environmental Crisis. Teoksessa M. E. Gomes \& A. D. Kanner (eds.) Ecopsyschology. Restoring the Earth, Healing the Mind. San Francisco: Sierra Club Books, 111-121.

Harva, U. 1968. Systemaattinen kasvatustiede. Neljäs painos. Helsinki: Otava.

Hobbes, T. 1985. Leviathan. London: Penguin books.

Jung, C. G. 1972. Two Essays in Analytical Psychology. 2nd edition. H. Read, M. Fordham, G. Adler \& W. McGuire (eds.) The Collected Works of C. G. Jung, Volume 7. Bollingen series XX. Translated by R. F. C. Hull. Princeton: Princeton University Press.

Järvilehto, T. 1994. Ihminen ja ihmisen ympäristö. Systeemisen psykologian perusteet. Oulu: Pohjoinen.

Järvilehto, T. 2009. The Theory of the Organism-Environment System as a Basis of Experimental Work in Psychology. Ecological Psychology 21, 112-120. 
Keto, S. \& Foster, R. 2021. Ecosocialization - an Ecological Turn in the Process of Socialization. International Studies in Sociology of Education 30 (1-2), 34-52. DOI: https://doi.org/10.1080/09620214.2020.1854826.

Kurki, L. 2002. Persoona ja yhteisö. Personalistinen sosiaalipedagogiikka. Jyväskylä: SoPhi. Saatavissa https://jyx.jyu.fi/bitstream/handle/123456789/47926/3/ SoPhi68_978-951-39-6502-0.pdf (haettu 31.8.2021).

Locke, J. 1995. Tutkielma hallitusvallasta. Tutkimus poliittisen vallan oikeasta alkuperästä, laajuudesta ja tarkoituksesta. Suom. Mikko Yrjönsuuri. Helsinki: Gaudeamus.

Macpherson, C. B. 1962. The Political Theory of Possessive Individualism. Oxford: Oxford University Press.

Macy, J. 2009. Maailma rakastajana ja minuutena. Keinoja maailmanlaajuisen ympäristökatastrofin torjumiseksi. Helsinki: Basam books.

Macy, J. 2014. The Greening of the Self. Teoksessa L. Vaughan-Lee (ed.) Spiritual Ecology. The Cry of the Earth. Point Reyes: The Golden Sufi Center, 145-158.

Mahler, M. S., Pine, F. \& Bergman, A. 2002. The Psychological Birth of the Human Infant. Symbiosis and Individuation. London: Karnac.

Marglin, S. 2009. Dismal Science. How Thinking Like an Economist Undermines Society. New York: Oxford University Press.

Martusewicz, R., Edmundson, J. \& Lupinacci J. 2015. EcoJustice Education. Toward diverse, Democratic, and Sustainable Communities. New York and London: Routledge.

Merchant, C. 1983. The Death of Nature. Women, Ecology, and the Scientific Revolution. San Francisco: Harper \& Row.

Montagu, A. 1952. Darwin, Competition, and Cooperation. New York: Henry Schuman inc. Naess, A. 2016. Ecology of Wisdom. London: Penguin Books.

Nivala, E. \& Ryynänen, S. 2019. Sosiaalipedagogiikka. Kohti inhimillisempää yhteiskuntaa. Helsinki: Gaudeamus.

Orr, D. 1992. Ecological Literary. Education and the Transition to a Postmodern world. Albany: State University of New York Press.

Orr, D. 1994. Earth in Mind. On Education, Environment, and the Human Prospect. Washington: Island Press.

Plumwood, V. 2002. Environmental Culture: The Ecological Crisis of Reason. London: Routledge.

Pulkki, J. 2017. Kilpailun kasvatuksellisista ongelmista. Hyveitä 2000-luvulle. Tampere: Tampere University Press. Saatavissa https://repo.tuni.fi/handle/10024/102261 (haettu 31.8.2021).

Pulkki, J. 2020. Varsinainen minä ja henkisyys ekososiaalisen kasvatusfilosofian aspekteina. Kasvatus 51 (3), 302-316.

Pulkki, J., Saari, A. \& Dahlin, B. 2015. Contemplative Pedagogy and Bodily Ethics. Other Education. The Journal of Educational Alternatives 4 (1), 33-51. 
Pylkkö, P. 1998. Suomen kieli on vetäytymässä ja jättämässä meidät rauhaan toisiltamme. Niin \& Näin 1, 44-49. Saatavissa https://netn.fi/sites/www.netn.fi/files/netn981-17. pdf (haettu 31.8.2021).

Rorty, R. 1999. Philosophy and Social Hope. London: Penguin Books.

Roszak, T. 1993. The Voice of the Earth. An Exploration of Ecopsychology. New York: Simon \& Schuster.

Rousseau, J. J. 1905. Emile eli kasvatuksesta. Suom. J. Hahl. Helsinki: Suomalaisen kirjallisuuden seuran kirjapainon osakeyhtiö.

Ruitenberg, C. 2013. The Double Subjectification Function of Education. Teoksessa T. Szkudlarek (ed.) Education and the Political New Theoretical Articulations. Rotterdam: Sense Publishers, 89-105.

Saari, A., Jokisaari, O.-J. \& Värri, V. M. (toim.) 2014. Ajan kasvatus. Kasvatusfilosofia aikalaiskritiikkinä. Tampere: Tampere University Press.

Sachs, W. (ed.) 1996. Development dictionary. A guide to knowledge as power. Johannesburg, London: Witwaterstrand University Press \& Zed books.

Salminen, A. 2014. Öljy ja aurinko. Fossiilinen subjekti yleisessä taloudessa. Teoksessa K. Lummaa \& L. Rojola (toim.) Posthumanismi. Turku: Eetos, 289-305.

Salminen, A. 2015. Kokeellisuudesta. Historiallisesta avantgardesta jälkifossiiliseen elämään. Helsinki: Poesia. Saatavissa https:/poesia.fi/hallinta/wp-content/uploads/2015/12/ Antti-Salminen_Kokeellisuudesta_Poesia-2015.pdf (haettu 31.8.2021).

Salminen, A. 2016. Omavaraistava asubjektivaatio eli ei-inhimillinen egontuho fossiilimoderniteettia vastaan. Elonkehä 3/2016. Saatavissa http://www.elonkeha. com/2016/12/09/omavaraistava-asubjektivaatio-eli-ei-inhimillinen-egontuhofossiilimoderniteettia-vastaan/ (haettu 31.8.2021).

Salminen, A. \& Vadén, T. 2013. Energia ja kokemus. Naftologinen essee. Tampere: Niin \& Näin.

Salminen, A. \& Vadén, T. 2018. Elo ja anergia. Tampere: Niin \& Näin.

Salonen, A. \& Bardy, M. 2015. Ekososiaalinen sivistys herättää luottamusta tulevaisuuteen. Aikuiskasvatus 35 (1), 4-15.

Scheiner, S. M. \& Willig, M. R. 2008. A General Theory of Ecology. Theoretical Ecology 1, 21-29. DOI: https//doi.org/10.1007/s12080-007-0002-0.

Seed, J., Macy, J., Fleming, P. \& Naess, A. 1988. Thinking Like a Mountain. Towards a Council of All Beings. Philadelphia: New society publishers.

Sewall, L. 1995. The Skill of Ecological Perception. Teoksessa M. E. Gomes \& A. D. Kanner (eds.) Ecopsyschology. Restoring the Earth, Healing the Mind. San Francisco: Sierra Club Books, 201-215.

Schlamm, L. 2014. Individuation. Teoksessa D. A. Leeming (ed.) Encyclopedia of Psychology and Religion. 2nd edition. Springer, 866-870.

Shiva, V. 1996. Resources. Teoksessa W. Sachs (ed.) Development dictionary. A guide to knowledge as power. Johannesburg, London, New Jersey: Witwaterstrand University Press, 206-218. 
Siljander, P. 2002. Systemaattinen johdatus kasvatustieteeseen. Helsinki: Otava.

Taylor, P. W. 1997. Luonnon kunnioittamisen etiikka. Teoksessa M. Oksanen \& M. Rauhala-Hayes (toim.) Ympäristöfilosofia. Kirjoituksia ympäristönsuojelun eettisistä perusteista. Helsinki: Gaudeamus, 225-250.

Vadén, T. 2000. Unityö ja subjekti. Niin \& Näin 2000/4, 66-71. Saatavissa https://www. netn.fi/sites/www.netn.fi/files/netn004-18.pdf (haettu 31.8.2021).

Vadén, T. 2004. Mitä on paikallinen ajattelu. Niin \& Näin 2004/1, 49-55. Saatavissa https://www.netn.fi/sites/www.netn.fi/files/netn041-08.pdf (haettu 31.8.2021).

Vadén, T. 2010. Kaksijalkainen ympäristövallankumous. Pamfletti synnyistä. Tampere: Osuuskunta Rohkean reunaan.

Vadén, T. 2016. Modernin yksilön harhat ja ympäristötaidekasvatus. Teoksessa A. Suominen (toim.) Taidekasvatus ympäristöhuolen aikakaudella - avauksia, suuntia, mahdollisuuksia. Helsinki: Aalto ARTS Books, 134-142. Saatavissa https://shop. aalto.fi/media/filer_public/b9/d5/b9d5af0c-c63a-43b5-bacb-6f86cbccc859/ taidekasvatusymparistohuolenaikakaudella.pdf (haettu 31.8.2021).

Vadén, T. \& Hannula, M. 2003. Rock The Boat - Localised Ethics, the Situated Self and Particularism in Contemporary Art. Köln: Salon Verlag.

Vadén, T. \& Torvinen, J. 2014. Musical Meaning in Between: Ineffability, Atmosphere and Asubjectivity in Musical Experience. Journal of Aesthetics and phenomenology 1 (2), 209-230.

Värri, V. M. 2018. Kasvatus ekokriisin aikakaudella. Tampere: Vastapaino.

Wang, C.-L. 2016. Towards Self-realization: Exploring the Ecological Self for Education. Educational philosophy and theory 48 (12), 1256-1265. DOI: https://doi.org/10.108 0/00131857.2016.1158090.

White, L. Jr. 1997. Ekologisen kriisin historialliset juuret. Teoksessa M. Oksanen \& M. Rauhala-Hayes (toim.) Ympäristöfilosofia. Kirjoituksia ympäristönsuojelun eettisistä perusteista. Helsinki: Gaudeamus, 21-33.

Zoja, L. 1997. Individuation and paideia. Journal of Analytical Psychology 42, 481-505. 